\title{
Development of novel surface display platforms for anchoring heterologous proteins in Saccharomyces cerevisiae
}

Xiaoyu Yang ${ }^{1+}$, Hongting Tang ${ }^{1,3+}$, Meihui Song ${ }^{1}$, Yu Shen ${ }^{1}$, Jin Hou ${ }^{1 *}$ and Xiaoming Bao ${ }^{1,2^{*}}$

\begin{abstract}
Background: Cell surface display of recombinant proteins has become a powerful tool for biotechnology and biomedical applications. As a model eukaryotic microorganism, Saccharomyces cerevisiae is an ideal candidate for surface display of heterologous proteins. However, the frequently used commercial yeast surface display system, the a-agglutinin anchor system, often results in low display efficiency.

Results: We initially reconstructed the a-agglutinin system by replacing two anchor proteins with one anchor protein. By directly fusing the target protein to the N-terminus of Aga $1 \mathrm{p}$ and inserting a flexible linker, the display efficiency almost doubled, and the activity of reporter protein a-galactosidase increased by $39 \%$. We also developed new surface display systems. Six glycosylphosphatidylinositol (GPI) anchored cell wall proteins were selected to construct the display systems. Among them, Dan4p and Sed1 p showed higher display efficiency than the a-agglutinin anchor system. Linkers were also inserted to eliminate the effects of GPI fusion on the activity of the target protein. We further used the newly developed Aga 1 p, Dan4p systems and Sed $1 p$ system to display exoglucanase and a relatively large protein $\beta$-glucosidase, and found that Aga1p and Dan4p were more suitable for immobilizing large proteins.
\end{abstract}

Conclusion: Our study developed novel efficient yeast surface display systems, that will be attractive tools for biotechnological and biomedical applications

Keywords: Yeast surface display, Aga1, Dan4, Sed1, a-Agglutinin, Glycosylphosphatidylinositol (GPI)

\section{Background}

Cell surface display expresses a target protein or peptide on the cell surface through fusion of the target protein to an anchor protein. As a eukaryotic model microorganism, Saccharomyces cerevisiae (S. cerevisiae) is ideal for cell surface display because: (i) it is a "generally regarded as safe" microorganism; (ii) it is suitable for expressing eukaryotic proteins because post-translational modifications are conserved in eukaryotic organisms; (iii) its clear genetic background facilitates diverse genetic engineering; and (iv) its rapid growth is time-saving [1]. Yeast surface display systems have been used widely in vaccine

\footnotetext{
*Correspondence: houjin@sdu.edu.cn; bxm@sdu.edu.cn

${ }^{\dagger}$ Xiaoyu Yang and Hongting Tang to be considered as joint first authors

1 State Key Laboratory of Microbial Technology, Shandong University,

Qingdao 266237, People's Republic of China

Full list of author information is available at the end of the article
}

and antibody development, library screening, biosensor detection systems, and bioconversion [2]. Yeast surface display has become a powerful protein engineering tool for applications in biotechnology and biomedicine $[3,4]$.

Generally, heterologous proteins are fused with the anchor domain of cell wall proteins for surface display [5-7]. In S. cerevisiae, the cell wall proteins are composed of two major classes-: (i) glycosylphosphatidylinositol (GPI) proteins, and (ii) the family of proteins with internal repeats (PIR) [8]. PIR proteins are attached to $\beta$-1,3-glucan directly in the cell wall, through an alkali-sensitive linkage [9]. In S. cerevisiae, the PIR family includes Pir1p, Pir2p, Pir3p, Pir4p and Pir5p. GPI proteins contain a GPI anchor which is synthesized in the endoplasmic reticulum and transferred to the carboxyl terminus of the protein. These proteins are then transported to the cell wall through the 
(See figure on next page.)

Fig. 1 Optimization of the a-agglutinin anchor system. a Schematic representations of a-galactosidase (a-Gal)-a-agglutinin and a-Gal-Aga1p. b Flow cytometry analysis of a-Gal-a-agglutinin and a-Gal-Aga1p after 12-h incubation. c The a-Gal activities of a-Gal-a-agglutinin and a-Gal-Aga1 p after 12-h incubation. $\mathbf{d}$ Schematic representation of a-Gal-Aga1 $p$ with a linker. e Flow cytometry analysis of a-Gal-a-agglutinin with a linker and a-Gal-Aga1 $p$ with a linker after 12-h incubation. $\mathbf{f}$ Cell activities of a-Gal-a-agglutinin with a linker and a-Gal-Aga1p linker after 12-h incubation

Golgi apparatus [10]. Nearly 60 GPI proteins have been identified in S. cerevisiae $[8,11]$.

The most frequently used yeast display system is the commercialized GPI protein a-agglutinin system. This system consists of two subunits, Aga1p and Aga2p. Heterologous proteins are fused to the C-terminus of Aga2p, Aga2p forms a complex with Aga1p via disulfide bonds, and Agalp is anchored to the yeast surface through a GPIanchor. The a-agglutinin system has been applied widely in vaccine and antibody development, library screening and biosensor detection systems. For example, a potential oral live vaccine against chicken coccidiosis was developed by displaying the Eimeria tenella EtMic2 protein on the cell surface via a-agglutinin [12]. A single-chain Fv $(\mathrm{scFv})$ antibody library was anchored on the cell surface via a-agglutinin to screen $\mathrm{scFvs}$ that recognize various tumor marker antigens [13]. A bioreceptor mutation library was displayed on the cell surface to improve both the stability and the affinity toward ligands [14]. Although a-agglutinin is a widely used display system, the system requires two components that need to form a complex, i.e. Agalp and Aga2p. In addition, the heterologous proteins anchored on the cell surface via disulfide bonds may not be stable under reducing condition. The two-component a-agglutinin system has been reported to have lower display efficiency than a one-component system, such as the $\alpha$-agglutinin system [15]. Therefore, construction of new high-efficiency display systems for use in S. cerevisiae should be advantageous over available two-component system.

Several yeast surface display systems have been developed using GPI anchor proteins [16]. For example, the anchor domains of GPI proteins, including Cwp1p, Cwp2p, Aga1p, Tip1p, Flo1p, Sed1p, YCR89w, and Tir1p, were fused with $\alpha$-galactosidase $(\alpha-\mathrm{Gal})$ and the display efficiency was compared. Cwp2p and Sed1p showed higher surface display levels than the other proteins [7]. When $\beta$-glucosidase (BGL1) and endoglucanase II (EGII) were displayed using the Sed1p anchoring region and SED1 promoter, the enzyme activity was significantly higher than when using $\alpha$-agglutinin (Sag1) system [17]. Although Sed1p-based display is highly efficient, using one anchor protein to display multiple proteins may lead to display saturation and relatively low display efficiency of each protein. Notably, disruption of SED1 improved the display efficiency of BGL1 fused with Sed1p [18]. Therefore, developing new efficient yeast surface display systems remains essential for industrial applications.

In this study, we first reconstructed the a-agglutinin system, using only the GPI-containing domain of Agalp as the anchor protein, to improve the display efficiency of heterologous proteins. Moreover, several new display systems were also developed, and among them, a Dan4pbased system showed the best display efficiency. Linkers were then added between heterologous proteins and anchor proteins to increase the activity of the heterologous proteins.

\section{Results}

\section{Optimization of a-agglutinin anchor system to improve surface display efficiency}

a-Agglutinin is a cell wall protein consisting of Aga1p and Aga2p. When used as a display system, a heterologous protein is normally fused to the $\mathrm{C}$-terminus of Aga2p and co-expressed with Aga1p. The display of a heterologous protein depends on the formation of two disulfide bonds between Aga1p and Aga2p, which may result in low display efficiency. To improve the efficiency, we attempted to directly fuse the reporter protein $\alpha$-Gal to the N-terminus of Aga1p (Fig. 1a). FACS analysis showed that the surface display efficiency of Agalp was nearly doubled when compared with that for a-agglutinin (Fig. 1b). However, the cell activity of $\alpha$-Gal-Agalp was similar to that of $\alpha$-Gal-a-agglutinin (Fig. 1c). This result indicated that the Aga1p based anchor system had higher display efficiency, but the activity of $\alpha$-Gal did not increase as expected, presumably because the direct fusion of $\alpha$-Gal with the $\mathrm{N}$-terminus of Agalp affected $\alpha$-Gal activity. In a previous study, insertion of a linker consisting of Ser and Gly between anchor proteins and a lipase form Rhizopus oryzae improved the activity of the lipase [19]. Thus, a linker of 17 amino acids from the commercial plasmid pYD1 (Invitrogen, Carlsbad, California, USA) composed of Ser and Gly was inserted between Aga2p and $\alpha-G a l$ or $\alpha-$ Gal and Aga1p (Fig. 1d). After addition of the linker to both systems, the display efficiency of $\alpha$-Gal-Agalp was double that of $\alpha$-Gal-a-agglutinin (Fig. 1e). The activity of $\alpha-\mathrm{Gal}$ displayed by Agalp increased 39\% when compared with the activity of $\alpha$-Gal-a-agglutinin (Fig. 1f). These results demonstrate that the one-protein-mediated Agalp display system is better than the a-agglutinin 
a

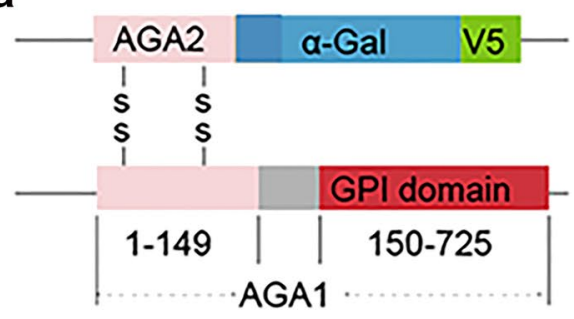

a-Gal-a-agglutinin

b
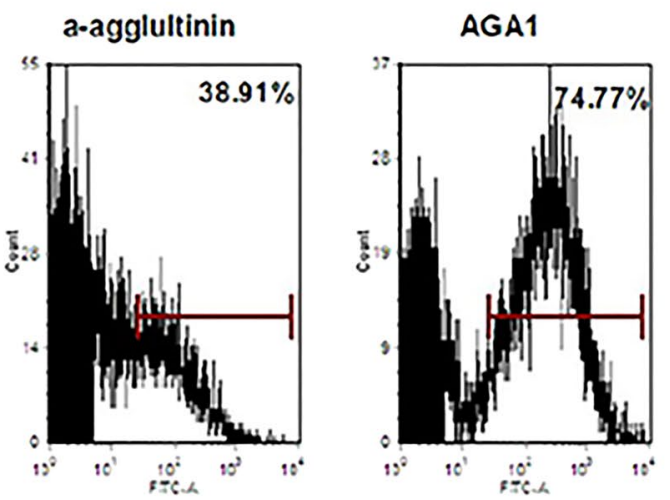

d

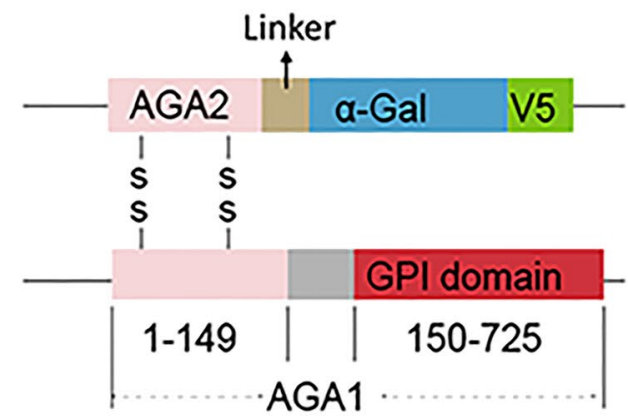

$\alpha-G a l-L-a-a g g l u t i n i n$

e

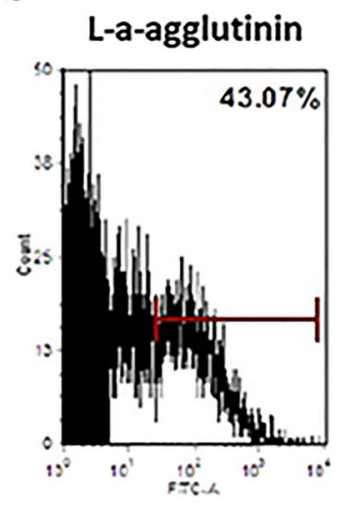

SP a-Gal V5 GPI domain 150-725 AGA1

$$
\alpha-G a l-A g a 1 p
$$
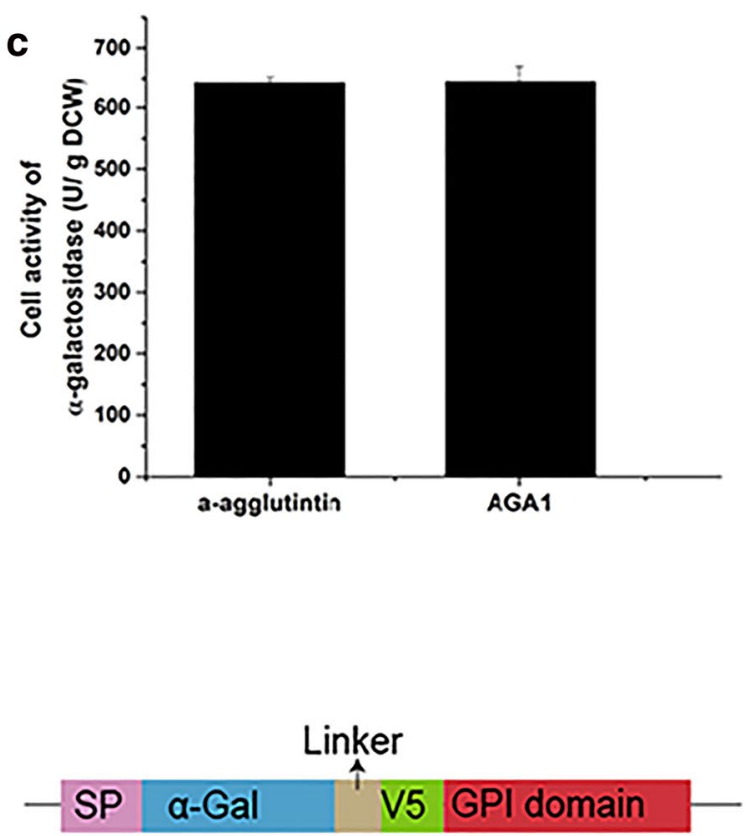

$\alpha-G a l-L-A g a 1 p$

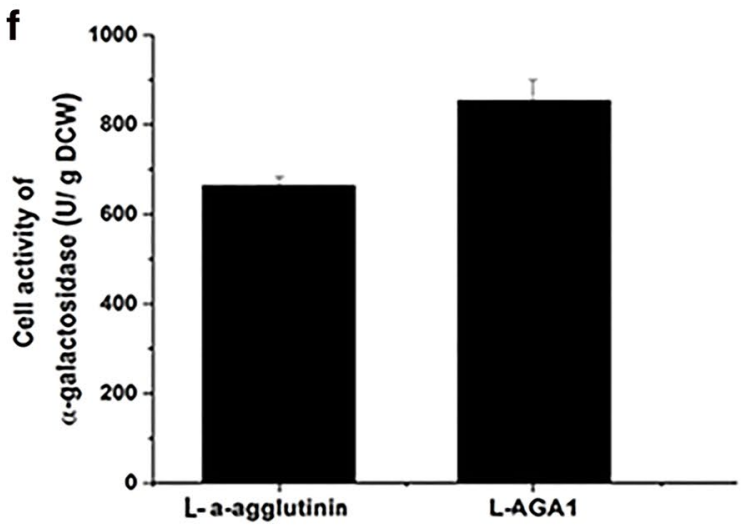


display system for yeast cell surface display of heterologous protein.

\section{Development of a new surface display system}

To develop a new efficient yeast surface display system, we selected six proteins from putative GPI-dependent cell wall proteins according to previous reported study [20], and used their serine- and threonine-rich region and GPI domain for protein display. The proteins selected included two reported display proteins, Sed1p and Cwp2p, and four novel proteins, Dan4p, Tos6p, Srp2p and Pry3p. $\alpha$-Gal was fused to the N-terminus of these selected anchor proteins. The design is shown in Fig. 2a. FACS analysis showed that $\alpha-G a l-D a n 4 p$ and $\alpha$-Gal-Sed1p had higher display efficiency than $\alpha$-Gal-aagglutinin and the other anchor proteins (Fig. 2b). Interestingly, the trends of cell enzyme activities were not fully consistent with the display efficiency. $\alpha$-Gal-Dan4p had the highest activity, and was $25 \%$ higher than that of $\alpha$-Gal-a-agglutinin. The fusion of $\alpha$-Gal with other anchor proteins did not increase enzyme activity (Fig. 2c). We observed that although $\alpha$-Gal-Sed1p had high display efficiency, the fusion with Sed1p did not increase enzyme activity, indicating that the activity of $\alpha$-Gal was affected by fusion with Sed1p.

In case there was an influence of the cell wall protein fusion on the target protein, we determined if enzyme activity could be enhanced by addition of a linker between the anchor protein and heterologous protein. The linker, containing 17 amino acids composed of Ser and Gly repeat sequence (as used above), was inserted between the anchor protein and the heterologous protein. After addition of the linker, the display efficiencies of these systems were improved by $6 \%$ to $14 \%$ (Fig. 3a). The enzyme activity was also enhanced by addition of the linker. $\alpha$-Gal-Sed1p showed the greatest improvement (Fig. 3b) with the enzyme activity increasing by $40 \%$ when compared with that of $\alpha-G a l-S e d 1 p$ without the linker. However, for other anchor proteins, addition of the linker only improved $\alpha$-Gal activity by $10 \%$ (Fig. 3b). The enzyme activity of $\alpha$-Gal-Dan4p was not increased by linker addition.

Here we have identified a new efficient display system Dan4p based system. From the data above, we conclude that Aga1p, Dan4p and Sed1p are potential candidates for yeast cell surface display of heterologous proteins.

\section{Yeast surface display of two cellulases using the newly developed anchors}

Exoglucanase $(\mathrm{CBH} 1)$ and BGL1 are responsible for hydrolysis of cellulose to glucose, and play essential roles in cellulose degradation. Currently, display of cellulases, including CBH1 and BGL1, on the surface of yeast cells, are widely studied for the consolidated bioprocessing (CBP) of cellulosic ethanol production [3, 4]. Thus, to test the applicability of the new yeast surface display system, CBH1 from Talaromyces emersonii and BGL1 from Saccharomycopsis fibuligera were fused with Aga1p, Dan4p or Sed1p and displayed on the Saccharomyces cerevisiae cell surface. As shown in Fig. 4a, when displaying CBH1 on the cell surface, all three systems showed high display efficiencies, with the CBH1-Dan4p-containing strain yielding the highest display efficiency. The cell enzyme activity was not fully consistent with display efficiency. Among the three $\mathrm{CBH} 1$-containing strains, the $\mathrm{CBH} 1$ Sed1p-containing strain had the highest activity (Fig. 4b).

In a previous study, we found that positively stained cells of a BGL1-containing strain were not detected by FACS when using a-agglutinin as the display system [21]. FACS analysis showed that the display efficiency of BGL1-Aga1p- and BGL1-Dan4p-containing strains was higher than that of the BGL1-Sed1p-containing and control strain (Fig. 4c). However, the number of positive stained cells of the BGL1-Sed1p-containing strain was not much higher than that of the control strain. The cell activity results were consistent with the FACS results. The cell activities of BGL1-Aga1p and BGL1-Dan4p were also higher than that of BGL1-Sed1p (Fig. 4d). BGL1Aga1p had the best performance among the systems examined. Compared with $\alpha-\mathrm{Gal}(39.8 \mathrm{kDa})$ and $\mathrm{CBH} 1$ $(48.7 \mathrm{kDa})$, BGL1 is a relatively large protein with a theoretical molecular weight of $96.2 \mathrm{kDa}$, and display on the cell wall may be more difficult. Thus, Aga1p and Dan4p may be more suitable for immobilizing large proteins.

\section{Discussion}

Yeast surface display is a very useful tool for protein engineering, and has wide biotechnological and biomedical applications. It can be used for construction of whole-cell biocatalysts, protein engineering, protein library screening, identifying protein-protein interactions, and mapping protein epitopes [22-29]. For efficient cell surface engineering, it is important to choose an appropriate anchor protein to obtain high display efficiency. Several yeast surface display systems anchored by Sed1p, Aga1-Aga2, Aga1, and Spi1p have been reported [15, $17,30-32]$. With the increasing needs of biomedical and industrial applications, further efficient yeast surface display systems are required.

Herein, firstly, we reconstructed the commercialized a-agglutinin surface display system, which normally consists of two subunits (Aga1p and Aga2p). The new Aga1p system developed herein directly anchored the target protein on the cell surface, and did not require the Aga2p subunit, which is frequently fused with the $\mathrm{N}$-terminus of the heterologous protein, and assembles with the cell 


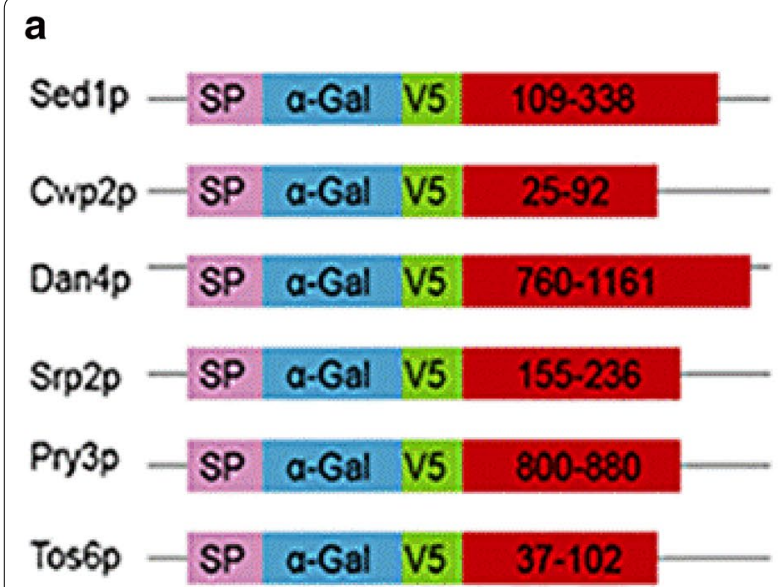

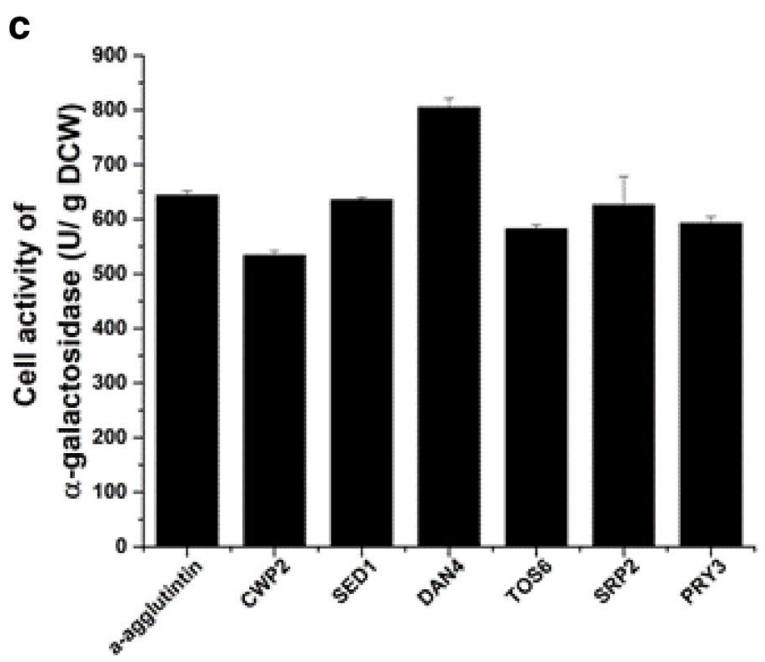

b

Control

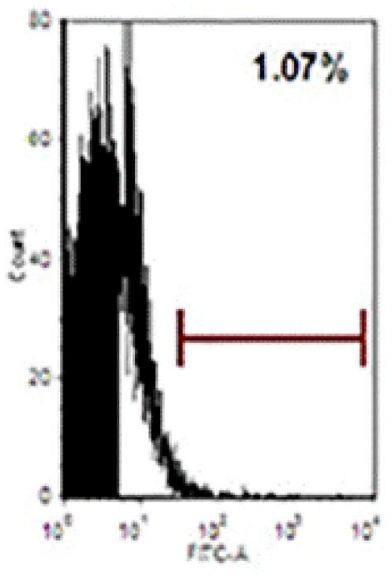

DAN 4

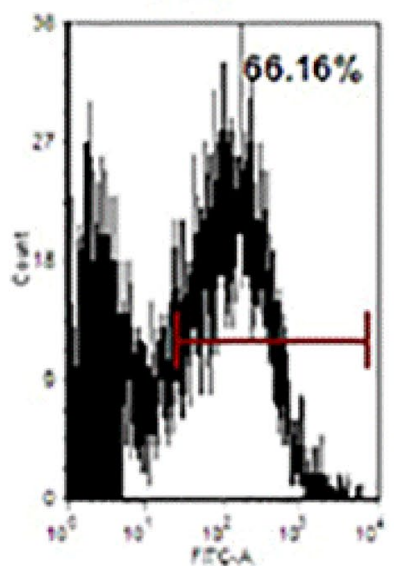

a-agglutinin

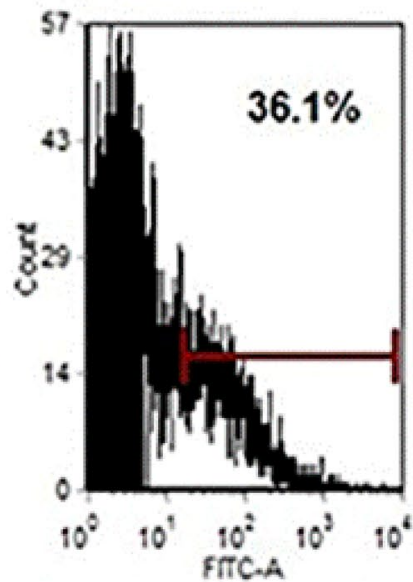

PRY3

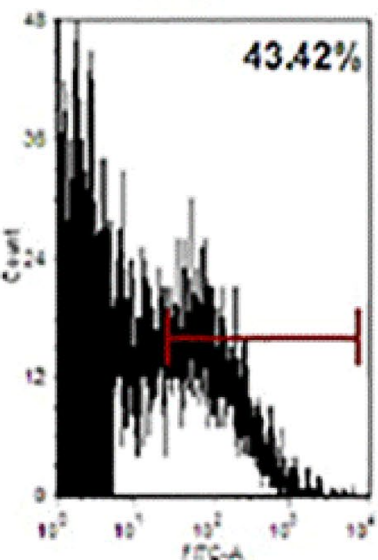

SED1

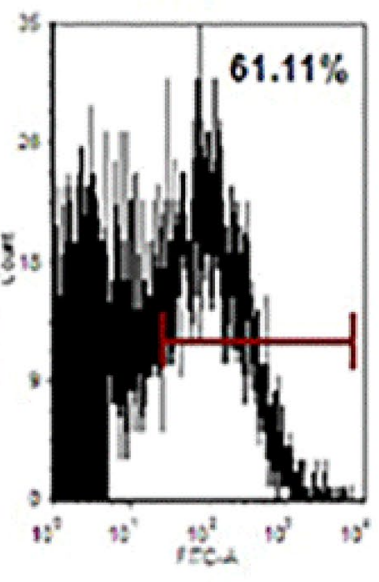

SRP2

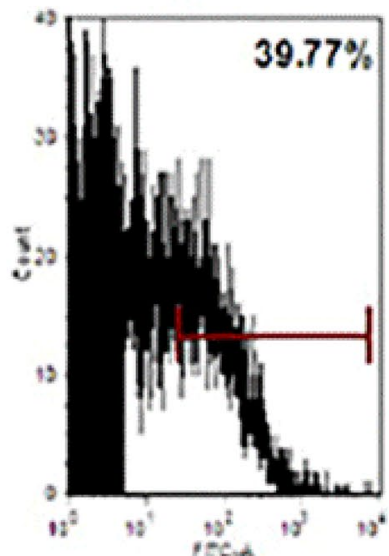

CWP2

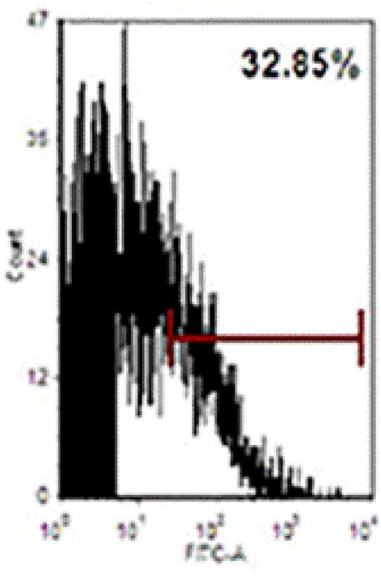

TOS6

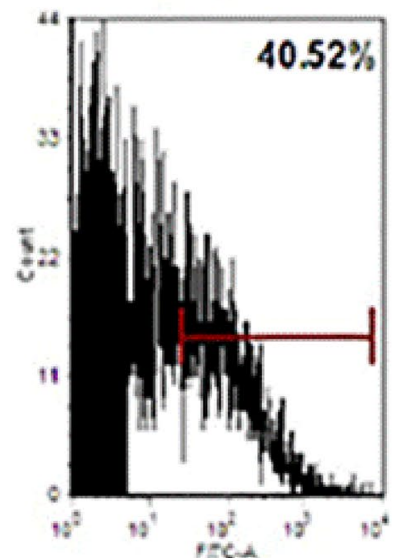

Fig. 2 Comparison of immobilization efficiencies of different cell surface display systems. a Schematic representations of the surface display systems constructed in this study. b Flow cytometry analysis of different systems after 12-h incubation. c Cell enzyme activities of seven anchoring systems after 12 -h incubation 

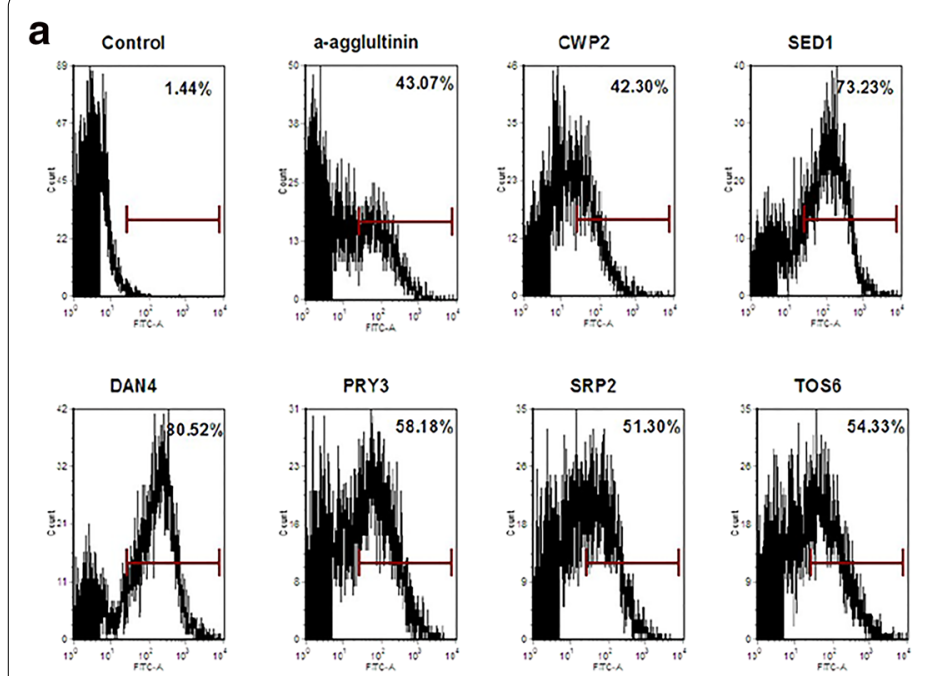

Fig. 3 Comparison of immobilization efficiencies of cell surface display systems after inserting a linker peptide. a Flow cytometry analysis of different systems after 12-h incubation. $\mathbf{b}$ a-Gal activities of seven anchoring systems

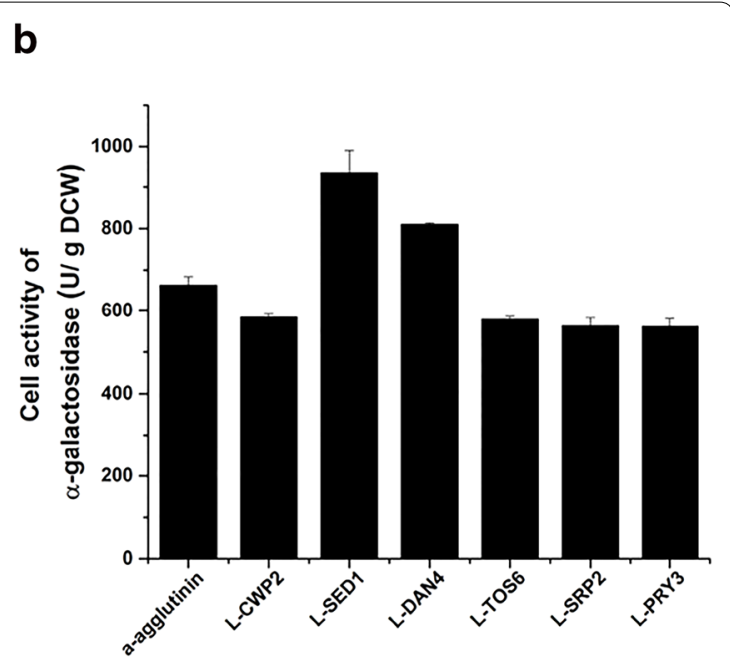

wall-anchored Aga1p via disulfide bonds. Disulfide bonds are complicated and sensitive to redox conditions, and our new Aga1p system avoids the potential drawbacks to provide a more stable system. The new system also showed higher display efficiency when compared with that of the standard two-component system.

In addition, we selected different cell wall proteins to construct novel display systems. By comparing the display efficiencies and enzyme activities of several display systems, we found that Dan4p showed good performance in surface display efficiency, similar to that of Sed1p. Recently, Phienluphon et al. [33] used bioinformatic analysis to identify potential anchoring proteins, and found that Dan4p had higher display efficiency than Aga1p, which is consistent with our results. More importantly, the surface display efficiency of the Dan4p system was not affected by the addition of a linker, whereas the Sed1p system is dependent on the linker. Thus, three display systems, containing Aga1p, Dan4p and Sed1p were selected as potential systems for immobilizing recombinant proteins on the surface of yeast.

In a previous study, we found that even though the cellulolytic enzyme BGL1, a large protein, was displayed on the yeast cell surface by the Aga1p and Aga2p system, positive stained cells were not detected by FACS analysis, whereas display of the endoglucanases CelA on the cell surface was detected by FACS. We hypothesized that this is because of the large size of BGL1 and the relatively low display efficiency with a-agglutinin. Here, we used Sed1p, Aga1p and Dan4p to display BGL1 to further compare these systems. Interestingly, the BGL1-Aga1p and BGL1-Dan4p systems showed higher cell enzyme activities and display efficiency than BGL1-Sed1p. The BGL1-Agalp system had more obvious advantage. Compared with Sed1p, Aga1p and Dan4p have a serine- and threonine-rich region and this region confers a rod-like structure to these two proteins [34]. This Ser/Thr rich region promotes cell wall integration and assists the cell wall protein to display their $\mathrm{N}$-terminus outside the cell wall [11]. The serine- and threonine-rich region of Agalp and Dan $4 \mathrm{p}$ also increases the distance between the target protein and the anchor protein, thereby reducing potential spatial interference between anchor and displayed proteins. Therefore, Aga1p and Dan4p may be more suitable for displaying large proteins.

\section{Conclusions}

Here, we reconstructed the a-agglutinin display system, and used one subunit (Agalp) for enhancing the display efficiency of heterologous proteins. Moreover, several novel anchoring proteins were compared. Sed1p, Aga1p and Dan4p showed good performance, and are candidates for displaying heterologous proteins on the yeast cell wall. These new display systems will be attractive tools for biotechnological and biomedical applications.

\section{Methods}

\section{Strains and media}

Escherichia coli strain Trans5 $\alpha$ (TransGen Biotech, Beijing, China) was used for plasmid propagation. Recombinant $E$. coli strains were grown in Luria-Bertani medium $(5 \mathrm{~g} / \mathrm{L}$ yeast extract, $10 \mathrm{~g} / \mathrm{L}$ peptone and $20 \mathrm{~g} / \mathrm{L} \mathrm{NaCl}$ ) with $100 \mathrm{mg} / \mathrm{mL}$ of ampicillin at $37^{\circ} \mathrm{C}$. S. cerevisiae strain CEN.PK102-5B [35] was used as the background strain 


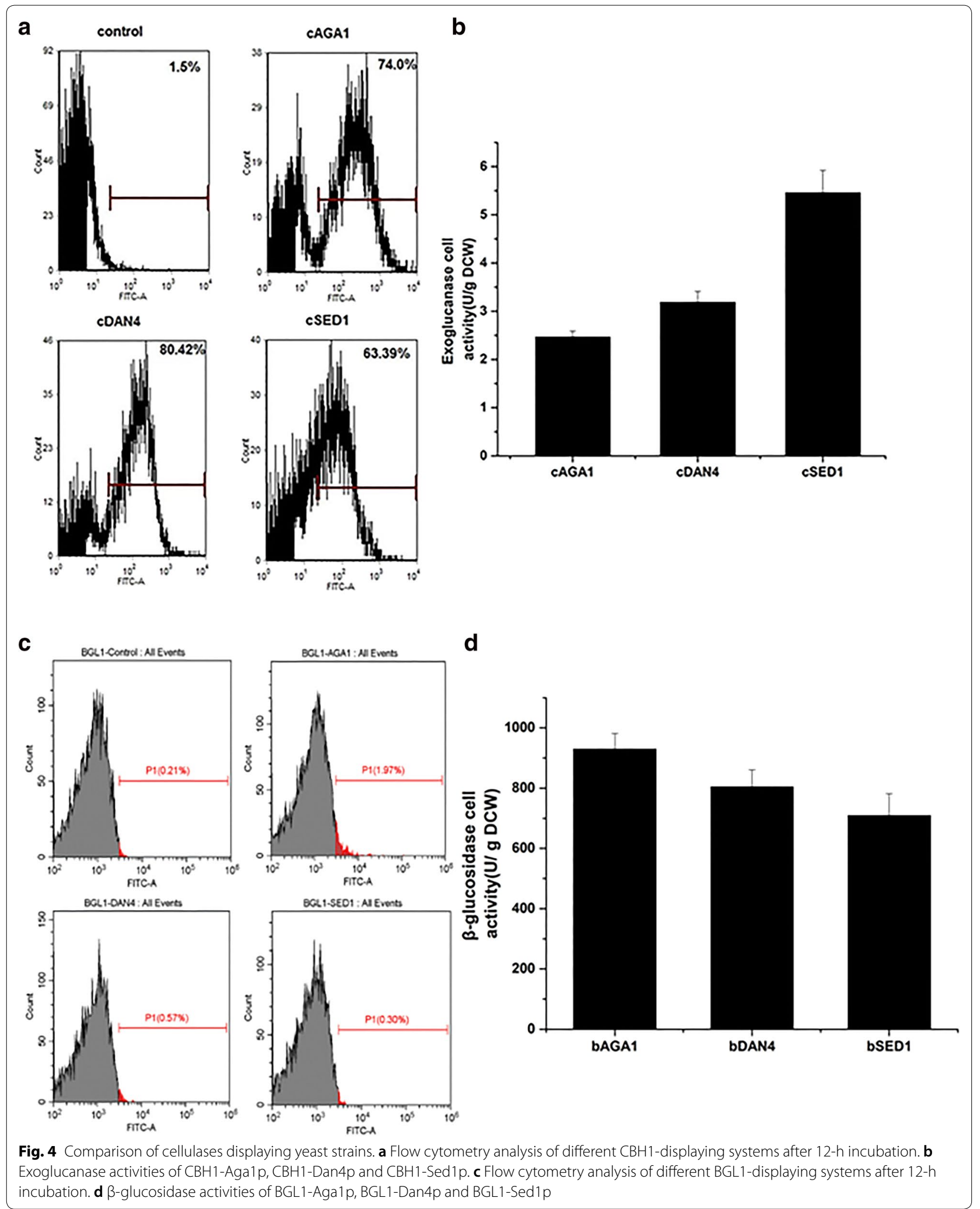


for surface display of heterologous proteins and was cultivated in YPD medium (1\% yeast extract, $2 \%$ peptone and $2 \%$ glucose). Recombinant strains were grown in $\mathrm{SC}-2 \times \mathrm{SCAA}$ medium without uracil, at $30{ }^{\circ} \mathrm{C}$, as previously described [36]. SC- $2 \times$ SCAA is composed of $6.9 \mathrm{~g} / \mathrm{L}$ yeast nitrogen base minus amino acids, $20 \mathrm{~g} / \mathrm{L}$ glucose, $2 \mathrm{~g} / \mathrm{L} \mathrm{KH}_{2} \mathrm{PO}_{4}$ (pH 6 by $\left.\mathrm{KOH}\right), 190 \mathrm{mg} / \mathrm{L}$ arginine, $52 \mathrm{mg} / \mathrm{L}$ tyrosine, $108 \mathrm{mg} / \mathrm{L}$ methionine, $290 \mathrm{mg} / \mathrm{L}$ isoleucine, $440 \mathrm{mg} / \mathrm{L}$ lysine, $200 \mathrm{mg} / \mathrm{L}$ phenylalanine, $400 \mathrm{mg} / \mathrm{L}$ aspartic acid, $1260 \mathrm{mg} / \mathrm{L}$ glutamic acid, $380 \mathrm{mg} / \mathrm{L}$ valine, $220 \mathrm{mg} / \mathrm{L}$ threonine, $400 \mathrm{mg} / \mathrm{L}$ leucine, $130 \mathrm{mg} / \mathrm{L}$ glycine, $40 \mathrm{mg} / \mathrm{L}$ tryptophan and $140 \mathrm{mg} / \mathrm{L}$ histidine.

\section{Plasmid construction}

Genes for heterologous expression and primers were synthesized and recombinant genes were sequenced by GENEWIZ (Suzhou, China). Plasmids and primers used are listed in Additional file 1: Tables S1 and S2, respectively. The $\alpha$-Gal gene [20] with signal peptide SUC2 from S. cerevisiae and a V5 tag or V5 tag with linker were synthesized and ligated into the yeast plasmid pJFE3 [37] under the control of the TEF1 promoter and PGK1 terminator to construct plasmids pJ $\alpha \mathrm{g}$ and $\mathrm{pJ} \alpha \mathrm{g}$-Linker. The C-terminal sequences of SED1 (687 bp), CWP2 (201 bp), SRP2 (243 bp), DAN4 (1203 bp), PRY3 (240 bp), TOS6 (195 bp) and AGA1 (1629 bp), for use in surface display systems, were amplified from S. cerevisiae genomic DNA, and were ligated into pJ $\alpha$ g and pJ $\alpha g$-Linker using Gibson assembly [38]. For surface display via a-agglutinin, the $\alpha$-Gal gene fused with $A G A 2$ was ligated into pJFE3, and $A G A 1$ (full-length) was also cloned into the plasmid to construct pJag-AGA12. The $C B H 1$ gene was synthesized and ligated into pJog-L-AGA1, pJog-L-DAN4 and pJogL-SED1 to construct pJCBH-L-AGA1, pJCBH-L-DAN4 and pJCBH-L-SED1 respectively. The BGL1 gene was amplified from the plasmid pTH-BGL [21] and ligated into pJog-L-AGA1, pJog-L-DAN4 and pJag-L-SED1 to construct pJBGL-L-AGA1, pJBGL-L-DAN4 and pJBGLL-SED1 respectively.

\section{Enzyme assays}

$\alpha$-Gal activity was measured using $p$-nitrophenyl- $\alpha$-Dgalactopyranoside ( $p$ NPGal; Sigma-Aldrich, St Louis, MO, USA) as the substrate as described previously [20]. Cells were collected and washed twice with $100 \mathrm{mM}$ sodium acetate buffer ( $\mathrm{pH} 4.5)$. The cell activity of $\alpha-\mathrm{Gal}$ was then measured. The cells were suspended in $100 \mathrm{mM}$ sodium acetate $(\mathrm{pH} 4.5)$ and incubated in $50 \mathrm{mM}$ citrate buffer ( $\mathrm{pH} 4.5$ ) with $5 \mathrm{mM} p \mathrm{NPGal}$ for $5 \mathrm{~min}$ at $37{ }^{\circ} \mathrm{C}$. The reaction was stopped by the addition of $1 \mathrm{~mL}$ of $2 \%$ $(\mathrm{wt} / \mathrm{vol})$ sodium carbonate and $p$-nitrophenol $(p \mathrm{NP})$ released from $p$ NPGal was determined at $405 \mathrm{~nm}$. One enzyme unit is defined as the amount of enzyme required to release $1 \mu \mathrm{mol}$ of $p \mathrm{NP}$ per min in the assay conditions.

CBH1 activity was measured using $p$-nitrophenyl- $\beta$-Dcellobioside ( $p$ NPC) as the substrate (Sigma) [39]. Cells were washed with $50 \mathrm{mM}$ citrate buffer $(\mathrm{pH} 4.8)$ and then incubated in $50 \mathrm{mM}$ citrate buffer $(\mathrm{pH} 4.8)$ with $5 \mathrm{mM}$ $p \mathrm{NPC}$ for $30 \mathrm{~min}$ at $50^{\circ} \mathrm{C}$. The reaction was terminated by the addition of $150 \mu \mathrm{L} 10 \%$ (wt/vol) sodium carbonate and the $p$-nitrophenol ( $p$ NP) released from $p$ NPC was determined at $405 \mathrm{~nm}$. One enzyme unit is defined as the amount of enzyme required to release $1 \mu \mathrm{mol}$ of $p \mathrm{NP}$ per minute under the assay conditions.

BGL1 activity was measured using $p$-nitrophenyl$\beta$-D-glucopyranoside ( $p$ NPG; Sigma) as the substrate, as described previously [40]. Cells were washed with $50 \mathrm{mM}$ citrate buffer ( $\mathrm{pH} \mathrm{5.0)}$ and then incubated with $5 \mathrm{mM} p$ NPG for $30 \mathrm{~min}$ at $50{ }^{\circ} \mathrm{C}$. The reaction was terminated by addition of $10 \%$ (wt/vol) sodium carbonate and $p$-nitrophenol ( $p \mathrm{NP}$ ) released from $p$ NPG was determined at $405 \mathrm{~nm}$. One enzyme unit is defined as the amount of enzyme required to release $1 \mu \mathrm{mol}$ of $p \mathrm{NP}$ per min under the assay conditions.

\section{Flow cytometry analysis}

Cells were harvested and washed twice with phosphate buffered saline (PBS, pH 7.0), and suspended in PBS with $1 \mathrm{mg} / \mathrm{mL}$ bovine serum albumin (BSA). The cells were diluted to an $\mathrm{OD}_{600}$ of 1.0 and $300 \mu \mathrm{L}$ of cell suspension was used as the sample for immunostaining. The monoclonal mouse anti-V5-FITC antibody (Invitrogen) was added to the samples at 1: 500 dilution at $25^{\circ} \mathrm{C}$ for $1 \mathrm{~h}$. The cells were harvested and washed twice with PBS after immunostaining. Flow cytometry analysis (FACS) used the FACSCanto II system (BD FACSCanto II, USA) and the CytoFLEX Platform (BECKMAN COULTER, USA).

\section{Additional file}

Additional file 1: Table S1. Plasmids used in this study. Table S2. Primer sequences used in this study.

Acknowledgements

We thank James Allen, DPhil, from Liwen Bianji, Edanz Group China (www. liwenbianji.cn/ac), for editing the English text of a draft of this manuscript.

\section{Authors' contributions}

$X Y, H T$ and $J H$ designed experiments. $X Y, H T$ and $M S$ carried out the experiments. $X Y, X B, J H$ and $Y S$ analyzed data. $X Y, H T$ and $J H$ wrote the manuscript. All authors read and approved the final manuscript.

\section{Funding}

This work was supported by the National Natural Science Foundation of China (31470219, 31770101 and 31711530155), Natural Science Foundation of Shandong Province (ZR2017ZB0210), the Key R\&D Program of Shandong Province (2017GSF21110), State Key Laboratory of Microbial Technology, Young 
Scholars Program of Shandong University and Key Laboratory of Chemical Biology (Ministry of Education) Open Projects Fund.

\section{Availability of data and materials}

All data generated or analyzed during this study are included in this published article and its Additional files.

\section{Ethics approval and consent to participate}

Not applicable.

\section{Consent for publication}

Not applicable.

\section{Competing interests}

The authors declare that they have no competing interests.

\section{Author details}

${ }^{1}$ State Key Laboratory of Microbial Technology, Shandong University, Qingdao 266237, People's Republic of China. ${ }^{2}$ Shandong Provincial Key Laboratory of Microbial Engineering, Qi Lu University of Technology, Jinan 250353, People's Republic of China. ${ }^{3}$ Center for Synthetic Biochemistry, Chinese Academy of Sciences, Shenzhen Institutes for Advanced Technologies, Shenzhen 518055, People's Republic of China.

\section{Received: 6 March 2019 Accepted: 7 May 2019}

Published online: 18 May 2019

\section{References}

1. Cherf GM, Cochran JR. Applications of yeast surface display for protein engineering. Methods Mol Biol. 2015;1319:155-75.

2. Bidlingmaier S, Liu B. Utilizing yeast surface human proteome display libraries to identify small molecule-protein interactions. Methods Mol Biol. 2015;1319:203-14.

3. Tanaka T, Kondo A. Cell-surface display of enzymes by the yeast Saccharomyces cerevisiae for synthetic biology. FEMS Yeast Res. 2015;15:1-9.

4. Tanaka T, Yamada R, Ogino C, Kondo A. Recent developments in yeast cell surface display toward extended applications in biotechnology. Appl Microbiol Biotechnol. 2012;95:577-91.

5. Liu W, Zhao H, Jia B, Xu L, Yan Y. Surface display of active lipase in Saccharomyces cerevisiae using Cwp2 as an anchor protein. Biotechnol Lett. 2010;32:255-60.

6. Schreuder MP, Brekelmans S, van den Ende H, Klis FM. Targeting of a heterologous protein to the cell wall of Saccharomyces cerevisiae. Yeast. 1993:9:399-409.

7. Van der Vaart JM, te Biesebeke R, Chapman JW, Toschka HY, Klis FM, Verrips CT. Comparison of cell wall proteins of Saccharomyces cerevisiae as anchors for cell surface expression of heterologous proteins. Appl Environ Microbiol. 1997:63:615-20.

8. Levin DE. Regulation of cell wall biogenesis in Saccharomyces cerevisiae: the cell wall integrity signaling pathway. Genetics. 2011;189:1145-75.

9. Ecker M, Deutzmann R, Lehle L, Mrsa V, Tanner W. Pir proteins of Saccharomyces cerevisiae are attached to beta-1,3-glucan by a new proteincarbohydrate linkage. J Biol Chem. 2006;281:11523-9.

10. Kinoshita T, Inoue N. Dissecting and manipulating the pathway for glycosylphos-phatidylinositol-anchor biosynthesis. Curr Opin Chem Biol. 2000;4:632-8.

11. Pittet $\mathrm{M}$, Conzelmann A. Biosynthesis and function of GPI proteins in the yeast Saccharomyces cerevisiae. Biochim Biophys Acta. 2007;1771:405-20.

12. Sun H, Wang L, Wang T, Zhang J, Liu Q, Chen P, Chen Z, Wang F, Li H, Xiao $Y$, Zhao X. Display of Eimeria tenella EtMic2 protein on the surface of Saccharomyces cerevisiae as a potential oral vaccine against chicken coccidiosis. Vaccine. 2014:32:1869-76.

13. Yuan X, Chen X, Yang M, Hu J, Yang W, Chen T, Wang Q, Zhang X, Lin R, Zhao A. Efficient construct of a large and functional scFv yeast display library derived from the ascites B cells of ovarian cancer patients by three-fragment transformation-associated recombination. Appl Microbiol Biotechnol. 2016;100:4051-61.
14. Richman SA, Kranz DM, Stone JD. Biosensor detection systems: engineering stable, high-affinity bioreceptors by yeast surface display. Methods Mol Biol. 2009:504:323-50.

15. Goyal G, Tsai SL, Madan B, DaSilva NA, Chen W. Simultaneous cell growth and ethanol production from cellulose by an engineered yeast consortium displaying a functional mini-cellulosome. Microb Cell Fact. 2011;10:89.

16. Kondo A, Ueda M. Yeast cell-surface display-applications of molecular display. Appl Microbiol Biotechnol. 2004;64:28-40.

17. Inokuma K, Hasunuma T, Kondo A. Efficient yeast cell-surface display of exo- and endo-cellulase using the SED1 anchoring region and its original promoter. Biotechnol Biofuels. 2014;7:8.

18. Bamba T, Inokuma K, Hasunuma T, Kondo A. Enhanced cell-surface display of a heterologous protein using SED1 anchoring system in SED1-disrupted Saccharomyces cerevisiae strain. J Biosci Bioeng. 2018;125:306-10.

19. Washida M, Takahashi S, Ueda M, Tanaka A. Spacer-mediated display of active lipase on the yeast cell surface. Appl Microbiol Biotechnol. 2001;56:681-6.

20. Hamada K, Fukuchi S, Arisawa M, Baba M, Kitada K. Screening for glycosylphosphatidylinositol (GPI)-dependent cell wall proteins in Saccharomyces cerevisiae. Mol Gen Genet. 1998;258:53-9.

21. Tang H, Song M, He Y, Wang J, Wang S, Shen Y, Hou J, Bao X. Engineering vesicle trafficking improves the extracellular activity and surface display efficiency of cellulases in Saccharomyces cerevisiae. Biotechnol Biofuels. 2017; 10:53.

22. Boder ET, Raeeszadeh-Sarmazdeh M, Price JV. Engineering antibodies by yeast display. Arch Biochem Biophys. 2012;526:99-106.

23. Holler PD, Holman PO, Shusta EV, O'Herrin S, Wittrup KD, Kranz DM. In vitro evolution of a T cell receptor with high affinity for peptide/MHC. Proc Natl Acad Sci USA. 2000;97:5387-92.

24. Kondo A, Shigechi H, Abe M, Uyama K, Matsumoto T, Takahashi S, Ueda M, Tanaka A, Kishimoto M, Fukuda H. High-level ethanol production from starch by a flocculent Saccharomyces cerevisiae strain displaying cellsurface glucoamylase. Appl Microbiol Biotechnol. 2002;58:291-6.

25. Ota M, Sakuragi H, Morisaka H, Kuroda K, Miyake H, Tamaru Y, Ueda M. Display of Clostridium cellulovorans xylose isomerase on the cell surface of Saccharomyces cerevisiae and its direct application to xylose fermentation. Biotechnol Prog. 2013;29:346-51.

26. Shiraga S, Kawakami M, Ishiguro M, Ueda M. Enhanced reactivity of Rhizopus oryzae lipase displayed on yeast cell surfaces in organic solvents: potential as a whole-cell biocatalyst in organic solvents. Appl Environ Microbiol. 2005;71:4335-8.

27. Shusta EV, Holler PD, Kieke MC, Kranz DM, Wittrup KD. Directed evolution of a stable scaffold for T-cell receptor engineering. Nat Biotechnol. 2000;18:754-9.

28. Van Deventer JA, Wittrup KD. Yeast surface display for antibody isolation: library construction, library screening, and affinity maturation. Methods Mol Biol. 2014;1131:151-81.

29. Cochran JR, Kim YS, Olsen MJ, Bhandari R, Wittrup KD. Domain-level antibody epitope mapping through yeast surface display of epidermal growth factor receptor fragments. J Immunol Methods. 2004;287:147-58.

30. Tsai SL, Goyal G, Chen W. Surface display of a functional minicellulosome by intracellular complementation using a synthetic yeast consortium and its application to cellulose hydrolysis and ethanol production. Appl Environ Microbiol. 2010;76:7514-20.

31. Yeasmin S, Kim CH, Park HJ, Sheikh MI, Lee JY, Kim JW, Back KK, Kim SH. Cell surface display of cellulase activity-free xylanase enzyme on Saccharomyces Cerevisiae EBY100. Appl Biochem Biotechnol. 2011;164:294-304.

32. Andreu C, Del Olmo ML. Development of a new yeast surface display system based on Spi1 as an anchor protein. Appl Microbiol Biotechnol. 2017;101:287-99.

33. Phienluphon A, Mhuantong W, Boonyapakron K, Deenarn P, Champreda $V$, Wichadakul D, Suwannarangsee S. Identification and evaluation of novel anchoring proteins for cell surface display on Saccharomyces cerevisiae. Appl Microbiol Biotechnol. 2019;103(7):3085-97.

34. Breinig F, Schmitt MJ. Spacer-elongated cell wall fusion proteins improve cell surface expression in the yeast Saccharomyces cerevisiae. Appl Microbiol Biotechnol. 2002:58:637-44.

35. Entian K-D, Kötter P. 23 yeast mutant and plasmid collections. In: Brown AJP, editor. Methods in microbiology, vol. 26. Tuite M: Academic Press; 1998. p. 431-49. 
36. Wittrup KD, Benig V. Optimization of amino acid supplements for heterologous protein secretion in Saccharomyces cerevisiae. Biotechnol Tech. 1994:8:161-6.

37. Peng B, Shen Y, Li X, Chen X, Hou J, Bao X. Improvement of xylose fermentation in respiratory-deficient xylose-fermenting Saccharomyces cerevisiae. Metab Eng. 2012;14:9-18.

38. Gibson DG. Enzymatic assembly of overlapping DNA fragments. Methods Enzymol. 2011;498:349-61.

39. Deshpande MV, Eriksson KE, Pettersson LG. An assay for selective determination of exo-1,4,-beta-glucanases in a mixture of cellulolytic enzymes. Anal Biochem. 1984;138:481-7.
40. Berghem LE, Pettersson LG. The mechanism of enzymatic cellulose degradation. Purification of a cellulolytic enzyme from Trichoderma viride active on highly ordered cellulose. Eur J Biochem. 1973;37:21-30.

\section{Publisher's Note}

Springer Nature remains neutral with regard to jurisdictional claims in published maps and institutional affiliations.
Ready to submit your research? Choose BMC and benefit from:

- fast, convenient online submission

- thorough peer review by experienced researchers in your field

- rapid publication on acceptance

- support for research data, including large and complex data types

- gold Open Access which fosters wider collaboration and increased citations

- maximum visibility for your research: over $100 \mathrm{M}$ website views per year

At BMC, research is always in progress.

Learn more biomedcentral.com/submissions 